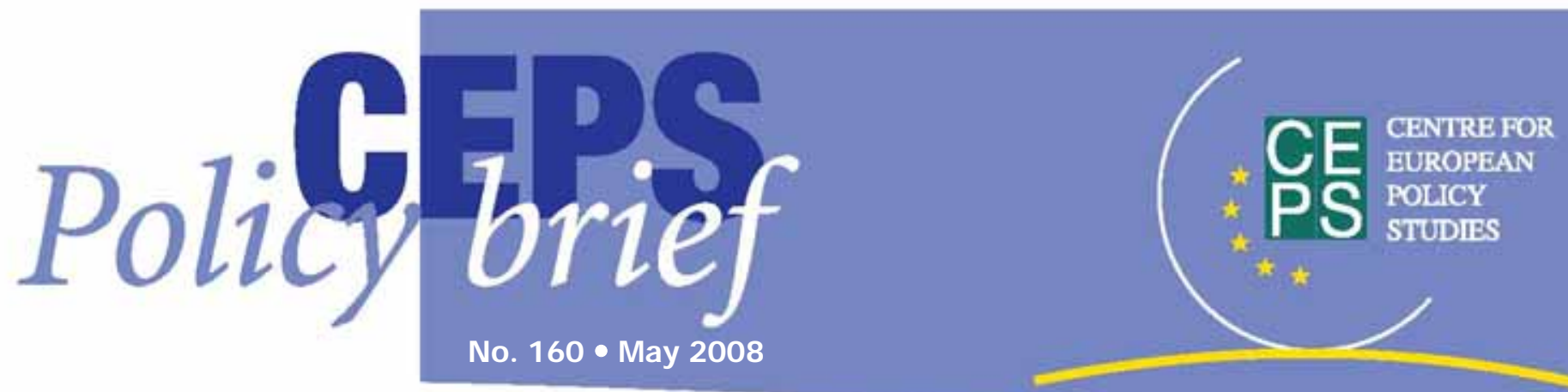

$\mathrm{T}$ he recent past has been a miserable time for political relations between Russia and both the EU and the US. While business has been booming on the back of Russia's huge gains from the skyrocketing price of oil and gas, the foreign policy scene has been desolate.

All parties are contributing to the present grumbling dissatisfactions: Russia's bullying foreign policy towards its smaller neighbours, its trouble-making over Kosovo and its ugly ultra-nationalist rhetoric, the EU's inability to shape common positions towards Russia on either political or energy questions, the greatly damaged credibility of the present leadership of the United States, Russia's complaints that it was cheated by NATO in the 1990s, the row over missile defences etc.

But renewal of leadership is now on the horizon in all three cases: in Russia already in May, in the US by the end of the year, and for the EU the Lisbon Treaty will bring at the turn of the year a new Presidency of the European Council and a reinforced role for the High Representative for foreign affairs.

Is it possible now to sketch the substantive moves that would allow the new leaders to transform the present sad state of affairs between Russia and the West? The case for doing so is strong. The West has a huge interest in integrating Russia into its economic, political and security structures, if that can be done in mutually acceptable ways. Europe and the West need to get their affairs in order together, to be better placed to face the new foreign policy challenges presented by the rise of Asia and the emerging multi-polar world.

The following package of four initiatives is proposed:

1. Russia should be invited to enter dialogue over the hypothesis of becoming a full member of NATO, leading to the working out of the necessarily huge preparatory agenda.

\footnotetext{
${ }^{1}$ The ultimate in MAD (mutually assured destruction - to use the terminology of nuclear weapon strategists) surrealism came in the debates in 2007 and 2008 over the US missile defence initiative, when Russia expressed concern that the
capacity of its strategic nuclear missiles to destroy West defence initiative, when Russia expressed concern that the
capacity of its strategic nuclear missiles to destroy West European capitals would be diminished.
}

2. The content of the next Treaty between the EU and Russia should be built around three strong points:

o Visa-free travel

o Free trade in goods and services

o A concordat on rules for reciprocal investment in energy.

3. Ukraine should be offered both a NATO membership action plan, and a perspective of EU membership.

4. The EU and US should work with Russia to help resolve the four 'simmering' (more than 'frozen') conflicts of the former Soviet space.

Russia wishes to be part of Europe on terms that it can accept. The package is intended to achieve a qualitative change in the perceived advantages and incentives to switch into a truly cooperative and integrative mode between the parties, leaving behind the present mode of discourse that reflects resentments and distrust.

The offer of the package would be the tipping-point, releasing huge positive possibilities that are currently blocked. During Putin's Presidency, Russia has repeatedly demonstrated that outside NATO and without a truly strategic partnership with the EU, it can cause a lot of trouble. The point has been made, accompanied at times by surrealist paranoid discourse. ${ }^{1}$ But for the future this only illustrates the scope for a better set of relations.

CEPS Policy Briefs present concise, policy-oriented analyses of topical issues in European affairs, with the aim of interjecting the views of CEPS researchers and associates into the policy-making process in a timely fashion. Unless otherwise indicated, the views expressed are attributable only to the author in a personal capacity and not to any institution with which he is associated. 


\section{NATO and Russia}

NATO is the key. Even if there are still grumbling irritations between Russia and NATO, the idea of the two parties truly drifting into a real new cold war is ridiculous. NATO and Russia share the same objective security threats. NATO has moved a long way in recent years into an organisation working at the level of 'coalitions of the willing'.

The lengthy communiqué of NATO's Bucharest summit in April 2008 serves as a comprehensive statement of the alliance's objectives. How would Russia's membership perspective relate to each of the major points?

i. Crisis management instruments: Russia could be a valuable contributor.

ii. Terrorism: Common interests are evident. Russia has a key role to play in preventing the risk of nuclear materials falling into terrorist hands.

iii. Conventional Forces in Europe (CFE) Treaty: Negotiated in the 1980s in the context of the cold war, this has become politically obsolete, although it was initially successful in reducing the number of tanks, armored vehicles and artillery pieces in the European theatre. The Treaty would be radically reconsidered in the new context, overriding negative developments (the West's non-ratification and Russia's recent withdrawal).

iv. Proliferation of weapons of mass destruction (WMD): Common interests are evident, and existing elements of cooperation such as over Iran and North Korea would be enhanced.

v. Missile defence: The great row of 2007-08 over the proposed US installations in Poland and the Czech Republic involves a subject matter that is inherently a desirable matter for collaboration with Russia, since it addresses common threats such as intermediate range missiles from Iran. The political context has hindered this, but would be transformed in the new context. Several mechanisms for technical collaboration over missile defence exist.

vi. Energy security: Russia's contribution could in the new context be massively important, indeed uniquely so.

vii. Cyber defence: This is a new area with cooperation potential.

viii.Afghanistan: There is already a degree of cooperation, with Russia's agreement to allow NATO over-flying rights. The common interests in countering the resurgence of $\mathrm{Al}$ Qaeda terrorism and the exports of drugs are evident. While Russia will not want to deploy troops there in view of its earlier Soviet experience, the scope for deeper cooperation exists. ix. Kosovo: 2008 marked the high point of disagreement over whether to recognise its independence. But now Kosovo is a de facto state with recognition by many but not all NATO and EU states. The future is about managing the new situation. In a new context Russia could become helpful, in providing reassurance to the Serb minorities.

x. Enlargement: The controversial cases of Ukraine and Georgia would be totally transformed in the context of Russia also approaching membership. President Putin has said as much.

xi. Frozen conflicts: The new context would provide the missing ingredient for the EU, the US and Russia to converge on making solutions - we return to the details below.

xii. Black Sea: With the prospect of both Russia's and Ukraine's accession to NATO, the highly inflammable situation in Crimea and Sebastapol would be greatly eased in the new context.

Of course there should be a preparatory period of sufficient length, for which the greatest of all membership action plans would have to be negotiated. A different method and terminology should be devised for Russia, rather than that used for some militarily insignificant newly acceding states. Russia's new Ambassador to NATO, Dmitry Rogozin, recently commented: "Great powers do not join alliances, they create alliances". Maybe we could settle for "recreating NATO"?

There would be no guarantee of accession, or this act of re-creation, with consensus of all existing member states required. But the political objective and new directions would be clear. But there should also be some immediately operational steps to make the bridge between today and tomorrow. Two examples come to mind.

First the NATO-Russia dialogue is insufficiently developed at the summit level. Only foreign ministers, ambassadors and officials meet regularly, but there is nothing remotely equivalent to the EU's half-yearly summits with Russia, where the EU is represented by the Presidency and the Commission. NATO has the problem that it does not have a presidency, and the international staff is not strongly institutionalised. The existing 26+1 (now becoming 28+1) format of the NATO-Russia Council, with all NATO member states and Russia, is useful but too cumbersome for a creative dialogue.

A new political mechanism is needed to give direction and coherence to its relations with NATO, alongside the EU. Ongoing changes to the G8 summit process open up one route. The G7 summit process was first enlarged to G8 to include Russia, but now this now seems set to go global and become G12, including 
Brazil, China, India and South Africa. There could therefore be a new G4 for Euro-Atlantic relations, with summits bringing together the EU (with its new leadership), Russia, the US and NATO (with its secretary general).

Second, there might be ways to build on the NATORussia Council towards something approaching partial membership of NATO. Initially certain NATO tasks where there already was consensus, or where consensus should be rather easily achieved, could be devolved to the NATO-Russia Council, starting for example with terrorism, WMD proliferation, cyber defence and certain crisis management operations.

\section{The EU and Russia}

Russia is not a plausible candidate for EU membership, because it is not willing to accept the intrusive mass of supranational laws, norms and standards that EU membership demands; and the EU could not plausibly envisage Russia's accession as the largest member state until and unless there was a revolutionary convergence of political norms and trust, which is not on the horizon.

However the EU and Russia are likely to begin negotiations soon for a comprehensive new Treaty. In the present political climate this is likely to be a thin document, consisting mostly of declarations of intention to cooperate, following the very extensive work of dialogue already underway for the so-called four common spaces: 1) Trade and Economic Cooperation, 2) Freedom, Security and Justice, 3) Research, Education and Culture, and 4) External Security. The agenda of these common spaces are encyclopaedic lists of topics, for many of which there are bilateral dialogue groups meeting regularly, as recorded in the Commission's progress reports. ${ }^{2}$ This in-depth engagement at the official level is certainly positive, but its operational content is so far lacking in strategic significance. To raise the level of ambition, there have to be a few strategic core features, whose significance will be self-evident to the population at large. Accordingly we propose three items as strategic priorities: visa-free travel, free trade and rules for investment in the energy sector; a fourth, concerning the simmering conflicts, is treated later since it also involves the US.

Visa-free travel. The feasibility of moving to a visafree regime between the EU and Russia has greatly improved. Visa facilitation and readmission agreements have recently entered into force. Already there are believed to be about 5 million Russians living in the

\footnotetext{
2 European Commission, "EU-Russia Common Spaces Progress Report 2007”, March 2007.
}

EU with no major problems emerging over the quality of their integration, except for post-Soviet tensions still in the Baltic states. At the same time economic conditions in Russia have categorically improved, with much increased salary levels and labour shortages leading now to tendencies of return migration back to Russia. Whereas in the early 1990s, visa-free travel would have triggered mass migratory movements, for these scenarios are receding. Instead there emerges a plausible model of two-way and circular migratory flows, which is exactly what is desired to facilitate a progressive integration and convergence of political values.

At least the words 'visa-free travel' are already on the official agenda. In April 2007, the EU and Russia agreed on procedures to examine the conditions for visa-free travel in the long run. Moreover there are new technical possibilities to retain checks and controls over the movement of individuals without recourse to visas. ${ }^{3}$ In February 2008, the Commission advanced ambitious proposals for an entry/exit registration system for all foreigners, whether they are required to possess a visa or not, based on a data base capable of storing biometric data. This may be complemented by an Electronic Travel Authorisation System, which would see non-EU travellers check on-line that their status reveals no negative indicators (and seems similar to a system that Australia already uses). Typically visitors profiting from visa-free travel are able to spend three months before having to request a residence permit. The Schengen Information System (SIS) will register individuals who overstay the period of their legally valid visit. ${ }^{4}$ The introduction of passports with strong security features and biometric recording of border crossings (thumb prints and eye scans) will provide safeguards against the use of falsified passports. Finally the existing re-admission agreement between the EU and Russia requires acceptance of the return of those ordered to leave because of the illegality of their stay. The time delay in establishing a visa-free regime with the new technological supports will be quite a number of years, but the key point for the shorter run is to set in motion a clear and viable plan, which now seems feasible.

Free trade. The second feature would be to enter into a free trade agreement. This is easy for the EU to propose, but more controversial for Russia, which is concerned by the poor competitivity of its industries outside the commodity sectors. But free trade offers to

\footnotetext{
3 Elspeth Guild, Sergio Carrera and Florian Geyer, The Commission's New Border Package - Does it take us one step closer to a 'cyber-fortress Europe'?, CEPS Policy Brief No. 154, March 2008.

${ }^{4}$ European Commission, "Communication on Preparing the next steps on border management of the European Union", COM(2008)69 final, 13 February 2008.
} 
Russia great advantages: alleviation of inflationary pressures, improvement in consumer welfare and favourable conditions for Russian industry to enter into global supply chains. Continuing protection means reinforcing the non-competitivity of Russian industry, which at some stage when commodity prices ease will become a real problem. Free trade negotiations could start immediately after Russia's WTO accession, and the prospect of this more ambitious scenario could provide the motivation to finally sweep away the remaining obstacles to WTO accession.

The EU proposes these days a doctrine of deep and comprehensive free trade with its neighbours, which however leaves ample scope for negotiating the precise depth of the agreement. Since the EU is preparing for deep free trade agreements with all its neighbours, and has already begun to negotiate with Ukraine, an agreement with Russia would open the prospect of completing a pan-Euro-Mediterranean free trade area. Russia is currently averse to adopting European standards, insisting on its own, but its high-level political discourse often seems to confuse matters of political principle and economic technicalities. In the field of tradeable product standards and the regulation of the major service sectors, Russia's political objective of 'modernisation' can be advanced by its economy aligning with best accepted international standards, which EU standards generally represent. ${ }^{5}$

Rules for the energy sector. The third feature would be in the energy sector, where President Putin has hinted at the possibility of a deal for mutual openness for investment. The difficulties here are well known, as illustrated by Russia's outright refusal to ratify the European Energy Charter and its proposed transit protocol, which would have limited Gazprom's monopoly control over its gas pipelines. However the two parties seem intent on making a bilateral energy agreement as part of the next Treaty. What are the prospects of this succeeding? The scale of the EURussia mutual interdependence is huge, which means that there should be scope for a mutually advantageous agreement, which negotiators have still to work out, that would clarify and consolidate the legal rules for investment and supply security.

A first requirement is for the EU itself to develop its own energy policy, which recent Commission proposals seek to do. ${ }^{6}$ In its internal aspects, a key feature would be to couple competitive integration of the internal market with the 'unbundling' of those enterprises that combine production, networks for

\footnotetext{
${ }^{5}$ This is illustrated in some detail in European Commission, "EU-Russia Common Spaces - Progress Report 2007", March 2007.

${ }^{6}$ European Commission, “An Energy Policy for Europe”, COM(2007)1.
}

wholesale distribution and retail distributors. This would apply without discrimination to both EU and foreign investors.

However investment in the control of transmission assets by foreigners from outside the EU would be contingent on the EU and the home country of the foreign investor entering into a bilateral agreement. This could lead naturally into the energy component of a next EU-Russia Treaty. The EU for its part would like to secure greater openness and stability in the conditions for its energy enterprises to invest in Russia. For its part Russia restricts foreign participation in strategic sectors, including energy, to less than controlling share holdings. The general principle would be to establish reciprocity for identified asset classes, with the possibility then to negotiate progressive dismantlement of restrictions on investment. ${ }^{7}$ An alternative view argues that cooperation with Russia should be based on investment in projects of common interest, such as energy efficiency, stopping the flaring of gas, and the capture and sequestration of $\mathrm{CO}_{2}$ emissions. $^{8}$

\section{Ukraine, NATO and the EU}

Ukraine is struggling to consolidate its democracy, its unity as a state and its drive to become fully part of the Euro-Atlantic community. It is receiving mixed signals from European countries, which are divided over whether to offer the perspective of membership of either EU, or NATO, or both. Both the EU and NATO have proven methods to prepare applicants for membership. The Communiqué of the NATO Bucharest summit of April 2008 concluded:

NATO welcomes Ukraine's and Georgia's
Euro-Atlantic aspirations for membership of
NATO. We agreed that these countries will
become members of NATO ... Membership
Action Plan (MAP) is the next step for Ukraine
and Georgia on their direct way to
membership. ...We have asked foreign
ministers to make a first assessment of
progress at their December 2008 meeting.

This seemingly highly positive language masked deep divergences among European states, with France and Germany blocking the opening of the MAP process at least for the time being. President Putin lobbied hard to block such a decision for both Ukraine and Georgia, saying that it would lead to the division and destruction of the Ukrainian state, while hinting that if Russia were

\footnotetext{
7 Dieter Helm, “The Russian dimension and Europe's external energy policy”, mimeo, Oxford University (www.dieterhelm.co.uk).

${ }^{8}$ Claude Mandil, "Sécurité énergétique et Union Européenne - Propositions pour la présidence française”, Rapport au Premier Ministre, 21 avril 2008.
} 
to be truly integrated into Western defence structures the problem would be dissolved. While questions concerning Ukraine or Georgia's military preparedness for membership are real, the issue at heart was supremely political, as eloquently argued on the eve of the Bucharest summit in the pages of Le Monde.

Tomorrow opens at Bucharest the summit meeting of NATO, the most important since the end of the cold war, and we wish to recall the hundreds and thousands of students, peasants and workers who invaded the streets of Tbilisi and Kiev [during the Rose and Orange Revolutions] brandishing European, French, German, English and American flags. These unarmed men and women were the worthy successors of Vaclav Havel, Lech Walesa, the East German pastors and the Hungarian and Romanian intellectuals. They incarnated Europe, that great adventure of our times of which, from Paris to Berlin, we have such difficulty in grasping its exalting and revolutionary aspect. They demand today to be associated with the organisation that has for almost 60 years assured the security of our democracies. In whose name do we refuse them? Who dares assume responsibility before future generations for slamming the door on their noses at so decisive a moment for their history and ours? ${ }^{9}$

The EU confronts exactly the same issue over whether to offer a 'membership perspective' to Ukraine. The EU is similarly divided like NATO. Poland, most new member states, the Baltic member states and the UK support the granting of these seemingly sacred words, which do not contain any guarantee, but only hope. Again France and Germany lead the opposition. Negotiations are engaged for a New Enhanced Agreement, which will incorporate a deep free trade agreement, while the political language is today likely to fall short of a clear membership perspective. However the EU has not hit gridlock with its recent enlargement, and the Lisbon Treaty improves the institutional system. If this proves insufficient in some years from now, let the system be improved again.

\section{Purging the simmering conflicts}

Transnistria, Abkhazia, South Ossetia and Nagorno Karabakh are no frozen conflicts. All are in motion, or risk the outbreak of new violence. Their resolution, or at least a neutering of their potential for violence and political destabilisation, would be among the necessary confidence-building measures in preparing for Russia's accession to NATO. Plausible scenarios for purging

9 Andre Gluksman and Bernar-Henri Levy, "Accueillez l’Ukraine et la Georgie”, Le Monde, 2 avril 2008 [our translation]. these simmering conflicts exist, but unity of purpose between the three big external parties - Russia, the US and the EU - could be decisive. The many years of fruitless diplomacy around all four conflicts have at least served to sort out the scenarios between the hopeless and more plausible. So far, Russia manifestly sees its national interest in sustaining tensions over Transnistria, Abkhazia and South Ossetia. The new context could change this. As and when the three external powers demonstrate credible unity of purpose, the principal parties will themselves understand a new context within which to negotiate. The starting point for each of these negotiations is outlined briefly below.

Transnistria. The closest to resolution, negotiations between the parties to this conflict are ongoing, including at the $5+2$ format (Russia, Ukraine, EU, US, and OSCE + Moldova and Transnistria). The European factor is at work, with Transnistria's industrial enterprises having increasingly opted to register as Moldovan enterprises in order to gain access to the EU market. In addition the EU's Border Assistance Mission on the Moldovan and Ukrainian borders with Transnistria helps to reduce illegal trafficking and improve trust. A federative solution is not agreed, but variants have been tabled.

Abkhazia. The situation is one of serious tension and some violence (a Russia MIG shot down a Georgian unmanned drone flying over Abkhazia in April 2008). President Saakashvili's insistence on a final federative solution met intransigent rejection. Russia has taken steps amounting to creeping recognition, if not annexation. The softly spoken consensus in the West is that Saakashvili's pursuit of a federative solution is not today the way ahead, and that Tbilisi should open its road and rail frontiers to Abkhazia to allow commerce and personal contacts to deepen. A partial territorial adjustment, with the Gali district returning to Georgia is conceivable. The question of a final constitutional settlement should be deferred for years, to allow normal relations between people and businesses to start up again and broadly develop.

South Ossetia. This situation also entails serious tensions and some violence (a Russian air force fighter dropped a missile near a Georgian radar in August 2007). This scattering of villages - some Russian-speaking, some Georgian - makes no sense as a political entity, except as an outpost of Russian attempts to weaken Georgia. The villages and towns can plausibly have local government responsibilities, for example choosing their preferred language regimes for schools.

Nagorno Karabakh. At least here Russia, the US and France, as co-chairs of the OSCE 'Minsk group' mediation effort, are relatively united, and have advanced proposals. The latest one is believed to based on the withdrawal of Armenian forces for occupied 
Azeri territories surrounding Nagorno Karabakh itself, which would disenclave Nakichevan, see the reopening of the railway line between Baku and Yerevan and grant Armenia a guaranteed corridor into Nagorno Karabakh. Turkey could add the re-opening of its frontier with Armenia. Both Armenian and Azeri sides seem to believe that time is on their sides with the status quo, with Azerbaijan believing that its oilrevenue funded rearmament will tip the balance of military power in its favour in due course. Russia, the US, the EU and Turkey could together make it clear to the 'party of war' in Baku that there can be no such solutions.

\section{Conclusion - Organising the tipping point}

The objective is to identify a sufficient package of steps of manifest strategic significance for both governments and public opinion such that Russian relations with the EU and the US would not just improve but reach a tipping point. This would replace the current miserable political climate of mutual criticism with a new era of historic significance.

Post-Soviet Russia has been through two episodes: first Yeltsin's revolutionary but chaotic dismantling of communism, and then Putin's consolidation of the Russian state internally and externally. Putin's consolidation has come with a strident nationalist political discourse, which in foreign policy has for Westerners had disturbingly aggressive and even paranoid aspects. Perhaps this episode may now come to an end.

One may speculate further that Russia could be on the verge of a third stage, to emerge maybe gradually after the change of presidency, in which a richer and selfconfident Russia might be open to a categorically more positive relationship with Europe in particular. This would be because Russia wishes to be included in modern Europe, without seeking membership of the $\mathrm{EU}$, and sees the case for a more attractive re-branding of its foreign policy profile, thereby securing objective advantages for its people, economy and political strategy.
Our leaders all say they are against new dividing lines within Europe. But do they mean it? Or, more precisely, are they capable of envisaging steps to dissolve the discursive divisions that exist today with Russia, and clarify for Ukraine whether it is really set to integrate with the Euro-Atlantic institutions or is destined to remain a fuzzy borderline case.

Our argument is that these divisions and confusions will remain unless the strategic framework is clarified, with:

o an invitation to Russia to open a fundamental dialogue over the perspective of NATO membership, and the conditions that would go with this; the process could be started with intermediate steps of institutional and operational content;

0 an offer by the EU to include clear strategic objectives in its next Treaty with Russia; and

o a clear offer of membership perspective to Ukraine from both NATO (i.e. membership action plan) and the EU (here the membership perspective language in the next Treaty would be sufficient).

One type of Western position is to say that potential members of NATO and/or the EU should demonstrate their will to converge on Western/European values and standards before raising 'premature' questions of future membership. This kind of position is clearly relevant for Russia in relation to NATO, and for Ukraine in relation to both NATO and the EU. But such positions beg questions of strategic political psychology and of incentives. What is attractive or acceptable with a membership perspective may be too costly without it. There can be different political equilibrium positions in relation to the complex agenda of organisations such as NATO and the EU, with these equilibria reinforced by synergies between agenda items, according to whether or not the context is that of a perspective of membership. The task is to organise the tipping point to switch from one equilibrium to another. The time horizon for this may be quite long, but the short-term issue is whether to place a visible objective on the horizon.

To start the process, there is need for institutional improvements to enhance strategic dialogue, especially between NATO and Russia. Accordingly it is suggested that arrangements are made for a regular-summit level dialogue of the NATO-Russia Council and/or for a new G4 summit process (for Russia, US, EU and NATO) given the expected widening of G8. 


\section{CEPS Publications}

\section{CEPS Paperbacks}

A Different Country: Russia's Economic Resurgence, Lúcio Vinhas de Souza, May 2008

Engaging Central Asia: The European Union's New Strategy in the Heart of Eurasia, Neil Melvin (ed.), May 2008

Travels among Europe's Muslim Neighbours: The Quest for Democracy, Joost Lagendijk, April 2008

Who is a normative foreign policy actor? The European Union and its Global Partners, Nathalie Tocci (ed.), May 2008

Beyond Bali: Strategic Issues for the post-2012 Climate Change Regime, Christian Egenhofer (ed.), April 2008

\section{CEPS Task Force Reports}

The New Basel Capital Accord: Remaining Challenges, Rym Ayadi, May 2008

Towards a Long-Term Climate Strategy for Actions:Measures for Structural Change and Technology Diffusion on a Global Scale, Noriko Fujiwara and Christian Egenhofer, May 2008

Global Sectoral Industry Approaches to Climate Change: The Way Forward; Christian Egenhofer and Noriko Fujiwara, May 2008

Pouring Old Wine into New Skins?UCITS \& Asset Management in the EU after MiFID, Karel Lannoo and JeanPierre Casey, April 2008

Energy Policy for Europe: Identifying the European Added-Value, Arno Behrens and Christian Egenhofer, March 2008

Corporate Taxation and the European Company Statute, Emrah Arbak, February 2008

\section{CEPS Special Report}

Is Social Europe Fit for Globalisation? A Study of the Social Impact of Globalisation in the European Union, Iain Begg, Juraj Draxler and Jørgen Mortensen, April 2008

The European Commission after Enlargement: Does more add up to less?, Sebastian Kurpas, Caroline Grøn \& Piotr Maciej Kaczyński, February 2008

\section{CEPS Policy Briefs}

No. 159 A new budget for the European Union?, Alfonso Iozzo, Stefano Micossi and Maria Teresa Salvemini, May 2008

No. 158 Checks and Balances: Dividing the Directorate General for Justice, Freedom and Security in two - an Interior and a Justice branch, Hasso Lieber, April 2008

No. 157 Iceland on the brink? Options for a Small, Financially Active Economy in the Current Financial Crisis Environment, Daniel Gros, April 2008

No. 156 What Future for the Area of Freedom, Security and Justice? Recommendations on EU Migration and Borders Policies in a Globalizing World, Didier Bigo, Sergio Carrera and Elspeth Guild, March 2008

No. 155 Making sense of Sarkozy's Union for the Mediterranean, Michael Emerson, March 2008

No. 154 The Commission's New Border Package: Does it take us one step closer to a 'cyber-fortress Europe'? Elspeth Guild, Sergio Carrera and Florian Geyer, March 2008

No. 153 What lessons can be learned from the EU emissions trading scheme?, Noriko Fujiwara and Christian Egenhofer, February 2008

No. 152 Using Markets to Secure European Energy Supplies, Arno Behrens, February 2008

No. 151 The EU's Limited Response to Belarus’ Pseudo ‘New Foreign Policy, George Dura, February 2008

No. 150 What do we know about the economics of adaptation?,Asbjørn Aaheim and Marianne Aasen, February 2008 


\section{About CEPS}

Founded in Brussels in 1983, the Centre for European Policy Studies (CEPS) is among the most experienced and authoritative think tanks operating in the European Union today. CEPS serves as a leading forum for debate on EU affairs, but its most distinguishing feature lies in its strong in-house research capacity, complemented by an extensive network of partner institutes throughout the world.

\section{Goals}

- To carry out state-of-the-art policy research leading to solutions to the challenges facing Europe today.

- To achieve high standards of academic excellence and maintain unqualified independence.

- To provide a forum for discussion among all stakeholders in the European policy process.

- To build collaborative networks of researchers, policy-makers and business representatives across the whole of Europe.

- To disseminate our findings and views through a regular flow of publications and public events.

\section{Assets}

- Complete independence to set its own research priorities and freedom from any outside influence.

- Formation of nine different research networks, comprising research institutes from throughout Europe and beyond, to complement and consolidate CEPS research expertise and to greatly extend its outreach.

- An extensive membership base of some 120 Corporate Members and 130 Institutional Members, which provide expertise and practical experience and act as a sounding board for the utility and feasability of CEPS policy proposals.

\section{CEPS carries out its research via its own in-house} research programmes and through collaborative research networks involving the active participation of other highly reputable institutes and specialists.

\section{Research Programmes}

Economic \& Social Welfare Policies

Energy, Climate Change \& Sustainable Development

EU Neighbourhood, Foreign \& Security Policy

Financial Markets \& Taxation

Justice \& Home Affairs

Politics \& European Institutions

Regulatory Affairs

Trade, Development \& Agricultural Policy

\section{Research Networks/Joint Initiatives}

Changing Landscape of Security \& Liberty (CHALLENGE)

European Capital Markets Institute (ECMI)

European Climate Platform (ECP)

European Credit Research Institute (ECRI)

European Network of Agricultural \& Rural Policy Research Institutes (ENARPRI)

European Network for Better Regulation (ENBR)

European Network of Economic Policy Research Institutes (ENEPRI)

European Policy Institutes Network (EPIN)

European Security Forum (ESF)

CEPS also organises a variety of activities and special events, involving its members and other stakeholders in the European policy debate, national and EU-level policy-makers, academics, corporate executives, NGOs and the media. CEPS' funding is obtained from a variety of sources, including membership fees, project research, foundation grants, conferences fees, publication sales and an annual grant from the European Commission.

E-mail: info@ceps.be

Website: http://www.ceps.be

Bookshop: http://shop.ceps.be 